\title{
Global Networks, Outside-In Capabilities and Smart Innovation
}

\author{
Silvio M. Brondoni*
}

\begin{abstract}
Starting from the early Sixties, and yet in the Seventies, competition imposed significant advancements in design and reengineering of products for the intense export policy into international markets pursued by large corporations.

The nowadays globalisation phase (competitive globalisation) is characterized by the $R \& D$ activities as a key-intangible asset, whose role is to develop the innovation and imitation policies of the large corporations, to anticipate demand trends and the initiatives of the competition, even collaborating with key competitors on particular projects.

Over-supplied markets emphasises the critical nature of research for customers empowerment because the condition of excess of production presents strongly unstable demand and unstable supply structures. In over-supply competition, research for customers empowerment maximises the opportunity to produce goods focused on design, smart innovation and creative imitation to satisfy specific demand bubbles.
\end{abstract}

Keywords: Network Management; Global Competition; Smart Innovation; Outside-In Capabilities; Corporate Design; Imitation; Innovation; Customers Empowerment

\section{Global Competition and Smart Innovation}

Globalisation has changed the traditional industrial principles. New flexible organisational forms emerge, postulating a global division of the structures in terms of space, time and the functions performed (Brondoni 2014).

In terms of space, manufacturing processes are not necessarily located permanently in a given place, but are usually shared between different companies and no longer require spatial proximity (Lambin 2014).

In terms of time, market-space management affects the temporal efficiency of production and supply chain; global networks replace sequential systems and processes, so that the manufacturing/delivery time configures all the manufacturing and logistics needs of the operating units in the network (Brondoni 2013).

\footnotetext{
*Full Professor of Management, University of Milan-Bicocca (silvio.brondoni@ unimib.it)
} 
Finally, in terms of the functions performed, global networks management tends to propose a fundamental change in the nature of relationships and collaboration with customers, partners and 'co-makers', overcoming the limits typical of 'interface cooperation', and striving rather to achieve closer and more selective interaction (outside-in management).

Globalisation, lean production, outsourcing, networking, digital ICT and the convergence of technologies (Corniani 2006) combine to substantially modify company management, focusing company policies on the development of innovations based on smart innovation.

\section{Global Competition, Corporate Design and Smart Innovation}

Global markets create new frontiers for competition and radically change temporal and spatial competitive relationships; specifically those linked, on the one hand, to time-based competition and, on the other, to the abandonment of closed domains deriving from particular physical or administrative spaces (a country, region, geographical area, etc.) (Lambin 2000).

In particular, starting from the early Sixties, and yet in the Seventies, competition imposed significant advancements in design and reengineering of products for the intense export policy into international markets pursued by large corporations with new products, which were designed with a back-up of external partners structures (international research centres, engineering \& project consulting firms, etc.). In these years, for example, Korea's 1960s and 1970s strategy was largely associated with duplicative imitations, producing on a large scale knockoffs or clones of mature foreign products, at significantly lower prices. (Kim 1997). In the same period, the Italian productions, locked in a 'castle economy' of protectionism and monopolies, had to compete without the resources of the country system and are often hindered by the deficiencies of the structures and infrastructures' (Brondoni 2008).

Since the 80s, given the markets globalisation springing up (product globalisation) (Brondoni 2014), the R\&D has faced a remarkable transformation. In fact, the firms operating in the global context produce their products with networking, outsourcing and time-based competition logic. In such revolutionary context of a 'market-space competition' (basically related to R\&D, operations and sales) unlike in the past, the capabilities, resources, competences and services readily outsourceable from global companies network become easily usable in space and in time (time-based competition) (Kleindorfer 1985).

In the same period, globalisation downsized the Product of Italy market ('Made in Italy'). Global competition laid down new rules and also imposed new conduct in the 'country identity system'. The 'Product of' was distinguished by the power of the 'macro-system intangible factors' (as in Product of USA and Product of Japan), or State aid for global exports (for example, Product of Korea) (Brondoni 2008).

In the 90s and 2000s the new globalisation phase changed the firms 'competitive landscape' for some specific phenomena referable to global firm's network (firm globalisation) (Brondoni 2014). 
The firms learned to act and decide rapidly, and the corporation success lied in the skills and processes aimed to a swift identification of opportunities and threats deriving from a technological discontinuity and from unexpected market development (Grossman, Helpman 1991; Meyers 1990).

Finally, since the early 2000s, a third globalisation phase (finance globalisation) (Brondoni 2014), has complicated the managerial model. In fact, in front of increasing competition, modest markets growth rates and over-supply conditions, they pushed the firm's performance, always more antagonistic in respect to the global financial market systems, to direct their R\&D expenses towards open innovation strategies (Brondoni 2013).

In global over-supplied markets, the firm's performance is conditioned by its ability to manage the design (of processes and products) as strategic tool that corporations use to gain a durable and sustainable competitive advantage, because imitation and innovation processes have become a primary condition to stand up to global competition on the markets (Brondoni 2012; Borja De Mozota, Young Kim 2009).

In this competitive landscape, the design (of processes and products) can be closely linked to smart innovation, seen as an 'outward looking' strategy focused on open policies of innovation (Bellini et al 2012; Asheim et al 2011).

\section{Global Markets, Open Innovation and Outside-in Management}

On global markets where competition is particularly fierce, the leading companies reveal the crucial importance of open innovation policies (Brondoni 2012).

Open innovation targets $\mathrm{R} \& \mathrm{D}$ at innovation and imitation processes simultaneously (Kim 1997; Helpman 1993; Cohen, Levinthal 1989; Link, Neufeld 1986; Levitt 1966), because companies tend to refer primarily to their competitors when they define their policies and when they organise research and development resources, highlighting an outside-in strategic approach, oriented to combine internal skills and knowledge coming from network relations with co-makers, partners and even competitors (Brondoni 2009; Arora et al. 2001).

In global markets, time-based competition and market-space management become crucial and determine the development of mega-organisations, whose success is conditioned by the level of sophistication of the corporate intangible assets. In other words the success is determined by the capacity to manage accumulated knowledge (inside-out knowledge resources) and the sum of knowledge that can be acquired externally through network relations (outside-in knowledge resources) (Brondoni 2011).

Nowadays, very frequently, innovative processes or products derive from the corporate ability to position the receptive points in strategic places of global markets so to capture new insights with an outside-in approach (Arrigo 2012 ).

Companies therefore acquire ideas, guidelines, resources, processes, etc. from outside, developing them internally to implement innovations and imitations that are competitive. These innovations and imitations are thus the result of corporate policies focused on competition (market-driven management) (Lambin, Brondoni 
2000), and bound by the objectives of short-term profitability and minimum market risk (Brondoni 2008; Weerawardena, O'Cass 2004; Vorhies, Harcher 2000).

On the other hand, global companies adopt closed innovation policies when they operate in sectors that are protected from competition (Utterback, Kim 1985; Mansfield et al. 1981; Abernathy, Utterback 1978). With closed innovation policies, the leading companies concentrate their expertise in governing innovation processes in internal structures, and intellectual property is defended against potential 'copying' and external appropriation. In conditions of global competition, closed innovation policies are distinguished by performance indices that refer to the generation of a 'theoretical' innovation potential, and typically regard: the costs met for R\&D activities; the number of patents developed and owned; the number of new products and modified products.

Open innovation stands out for the presence of distributed know-how (in network relations, and therefore within dedicated structures but also from outside, with competitors, consultants, suppliers, customers, etc.). The intellectual property, is no more concentrated primarily on defending acquired positions, as it is seen in markets that are closed to global competition.

In open markets where competition is strong, innovation therefore loses its role of 'ideological hierarchy' over imitation; both have the common goal of maximising company profitability, with the constraint of optimising performance results in the very short term. With open innovation the capacity to exploit the competition acquires prime importance, while the capacity to accumulate know-how becomes less important (Brondoni 2011).

Open innovation emphasizes the importance of capturing knowledge from the external environment and converting it into innovative processes, products or services (Arrigo 2012).

The partners within the supply chain are one of the most important sources of knowledge applied to develop innovative processes and the combination of the company know-how with those of suppliers, customers and external actors can increase the firm's innovativeness (Inauen, Schenker-Wicki 2011).

$\square$ "Open Innovation at GE. General Electric and start-up companies alike say they benefited from the company's call for ideas about the smart grid. General Electric had an innovative way to come up with innovations related to the emerging "smart" electric grid: the company asked for ideas. GE launched what it called an 'ecomagination challenge', a competition in which start ups and inventors were asked to present technologies that could help GE accelerate its development of products and services related to the smart grid. Since its 2005 launch, ecomagination - the company's commitment to technology solutions that save money and reduce environmental impact for its customers and GE's own operations - has generated more than US\$160 billion in revenue. GE got 4,000 submissions. It gave $\$ 100,000$ cash awards to five young companies and formed strategic partnerships with 12 others; all of them are expected to help GE's business in one way or another in such areas as energy storage, utility security, energy management software, and electric-vehicle charging services" (February 7, 2011). 
Also cooperation with competitors can represent another way to acquire knowledge; in fact, market-driven firms possess an absorptive capability (Cohen, Levinthal 1990) that facilitates learning from others firms and accelerates the implementation of new processes (Arrigo 2012).

Global corporations take advantage of a concept of competition space that underlines the exploitation of outside-in potential, adopting widespread and strongly inter-connected structures. In these complex organisations, relations inside the individual operating structures must be in step with more extensive systems of continuous connections maintained with co-makers and with external organisations (Brondoni 2011).

Inside the global network's alliances, market-driven firms share resources and knowledge and can learn from their competitors (Cambra-Fierro et al. 2011). As a matter of fact, market-driven firms tend to expand their innovation potential being open to the outside and the search activity is based on a continuous interaction with co-makers and partners (Arrigo 2012).

Collaborating with partners, customers, competitors or suppliers is now well recognized as an essential factor able to enhance firms' performance and innovativeness (von Hippel 1988). Market-driven firms, implementing an outsidein management, embrace the idea of treating innovation in an open way. Indeed, the open innovation expressly refers to the use of inflows and outflows of knowledge among many partners to accelerate internal innovation (Chesbrough 2003).

In 'enlarged competition space', global networks aim at overcoming the physical competition space (market-space management). Corporate culture plays a central role in the conduction of internal, external and co-makership relations, emphasising a farreaching concept of corporate belonging without local characterisation or any connotation of the physical space.

Globalisation, lean production, outsourcing, networking, digital ICT and the convergence of technologies combine to substantially modify company management, focusing company policies on the development of 'knowledge production'.

In global markets, conditions of market-space competition define the firm with particular characteristics, which are very different from those that emerge in the local districts, in markets characterised by limited international competition and physical, natural or administrative boundaries.

In industrial districts, firms tend to maintain production linked to the vocations, traditions and resources of specific geographical areas, and therefore does not usually draw on 'knowledge production'. What is more, when assessing performance, direct controllability and personal assessments prevail. Typical examples of local districts are local manufacturing districts, particularly those defended by natural boundaries and a limited openness to competition, dominated by strong conservatism of production and with limited corporate marketing, communication and finance policies (Brondoni 2002).

Globalisation forces companies to make competitive comparisons, and as a result communication and information flows, manufacturing decentralisation and operating accountability become critical in global networks (Brondoni 2011).

In order to exploit the growing returns deriving from outside-in relations (marketdriven management), global networks with a higher level of knowledge production favour relocations in metropolitan areas that simplify the availability, spread and capitalisation of knowledge economy. This is basically what occurred in industrial 
production in the early $20^{\text {th }}$ century thanks to the availability of manpower, energy and raw materials.

This process of change, which determines the complex development of network relations and new means of acquiring and transferring specific professional capabilities, involves numerous structures, in particular the large consultancy companies, the state-agencies dedicated to economic promotion and, above all (with a completely new role, which has strengthened significantly in the last 10-15 years of economic globalisation) the 'world cities', which have to meet the specific needs of the global networks (Brondoni 2011).

For global corporations, achieving a differential advantage in terms of product design means to develop a product based on the best interpretation of specific distinctive characteristics. For this purpose, information must be collected in continuum from the market, referred to customers and competitors, to understand the targets and to predict the future actions, even monitoring the threat of new competitors and any eventual replacement products, i.e. products that meet specific consumer needs in a different way or at a lower cost (Lambin, Brondoni 2001).

In particular, global markets express a new vision of corporate researches, consistent with the information needs of complex organisations (generally networkbased) working with several decision-making points (characterised by high-level of autonomy and responsibility) and with very brief action-reaction times (Koo, Cooper 2011; Brondoni 2010).

\section{Outside-In Capabilities for Innovation and Imitation in Global Network Management}

In the global world, corporations copy and succeed. The pace and intensity of legal imitation has quickened in the last twenty years. Global competition shows that imitators end up winners and global copying is now not only far commoner than innovation in business, but a surer route to growth and profits. Imitation does not necessarily imply clones of goods, or illegal counterfeits. In fact, the imitation can also be legal and very positive for the firm development (Brondoni 2012).

By contrary, creative imitations are a bright strategy for the firms with low wages and mature technology (Schnaars 1994). In general, creative imitations are focused on generating imitative products, but with new features. These imitative products involve benchmarking and strategic alliances, but also substantial investments in R\&D (Bolton 1993).

The development of global policies of innovation and imitation can be divided into four strategic patterns.

A first strategy stresses the strong correlation between R\&D intensity and multinational performance of corporation (Caves 1982). The international strategy of innovation (1970-1990) performs abroad increasing percentages of $R \& D$, while the prevailing tendency is still for research to remain based at the headquarters of MNCs.

A second strategy began in the 1990s, when the corporations dealt with the decentralization of $\mathrm{R} \& \mathrm{D}$, together with a rapid globalisation of networks. Networks would engage in foreign-based $R \& D$ to obtain: product or process 
improvements; research advances into basic materials or products; efficiencyseeking research to acquire foreign technological assets (Dunning 1993).

The third strategy is related to the globalisation of R\&D and the concept of global innovation networks (Ernst 2006). The process of $R \& D$ globalisation had highlighted the emergence of developing economies as locations for R\&D. It described the early stages of the rise of China as a location for foreign $R \& D$, several examples of R\&D global networks, such as Motorola or Toyota, and examples of R\&D undertaken by subsidiaries in South Korea (Byun, Ahn 1989), Brazil, Morocco, Kenya and Czech Republic.

The fourth, ongoing, strategy of global management of innovation emphasizes the importance of imitation in competitive global networking. This strategy coincide with the accelerated crisis of older forms of industrial organization in many global industries (Dunning 2008). The management of global innovation and imitation is driven by competition, increases in technological advances and accelerating cycles of customer preferences (Brondoni 2012).

\section{Global Competition, Creative Imitation and Smart Innovation}

Market globalisation and the growth objectives of large corporations accelerate competitive dynamics and step up the complexity of managing them, determining new problems in corporate strategies of imitation and innovation.

The nowadays globalisation phase (competitive globalisation) (Brondoni 2014) is characterized by a widespread and persisting recession of numerous economies, an increasing number of over-supplied markets, as well as a key-role of dimensional growth. The last one, in particular, represents a fundamental driver for the firm's development, by determining its success or decline (Brondoni 2012).

In fiercely competitive global markets, the $R \& D$ activities therefore become a key-intangible asset, whose role is to develop the innovation and imitation policies of the large corporations, to anticipate demand trends and the initiatives of the competition, even collaborating with key competitors on particular projects. In fact, in global markets the R\&D represents a key-intangible asset for all the innovation and imitation policies of the big companies, perfectly conscious of a value-creation power of the research structures. Many projects, in fact, are managed together with key-competitors in order to optimize the corporate performance and product performance, by realizing plans and programs of competitive imitation, destined to overtake traditional models of economic and industrial development (Brondoni 2012).

Thus, in this phase of competitive globalisation of markets, the R\&D structures assume a new key-role for the firm's development and represent a continuous stimulus for the competitive dynamics (Darroch 2005). In the modern corporations, the R\&D contributes to define the market sceneries and also to identify innovation and imitation policies. Such policies are naturally connectable to the profitability objective on one hand but limited by the new products launch-risk on the other.

The objectives of growth and short-term profitability constraints led the big corporations to prefer the R\&D multi-polar development. As a consequence, the structures are decentralized and developed in the form of innovation clusters (Cappellin, Wink 2009). Such condition of the R\&D multi-polarity allows the big 
networks to realize simultaneously multi-markets projects and as a consequence to nullify high common costs related to mono-project structures. Finally, it assures an extreme confidentiality of strategic corporate information (Doloi 2007).

In global corporations, the imitation processes represent a major effort that involves the development of advanced technologies and specific efforts to focus R\&D on new technologies.

The innovation is a pioneering activity focused on the firm's internal competences, to develop and introduce new products to the markets. Innovators benefit from first-movers advantages: awareness and image; technological leadership; experience effects; client loyalty; etc.

Whether it is alternative energy sources, interconnected traffic \& safety systems, human assisting robots or new modes of personal transport, Toyota is constantly focused on developing for the future. Toyota's new challenge, the Smart Mobility Society -a place where state-of-the-art technology connects people, cars, and communities to create a secure and happy society. Vehicle data from the nearly three million Toyota vehicles on the road in Japan really is big data. A number of experiments are underway to harness this information to create practical applications. Places where drivers are shown to often brake suddenly are designated as dangerous locations. Road condition data from these sites is collected from vehicle rear-view camera footage. This data can include information about indistinct road surface markings or buildings that obscure the field of view. In this way we can contribute to improved traffic safety. Toyota believes that the car of the future will be far more than a simple machine. By equipping vehicles with the latest in IT technology, we can build a more persona; relationship between people and their cars.

In global markets, by contrast, many industries extend their R\&D activities to transform themselves into innovators as well as effectively creative imitators, with corporate policies marked by intensified in-house R\&D activities and participation in global alliances (Bruce, Jevnaker 1998). Thus, these global creative imitators have transformed the R\&D activities into skills and competences necessary for the reverse engineering. Reverse engineering involved activities that sensed the potential needs in the market, activities that located knowledge or products which would meet the market needs, and activities that would merge these two elements into a new project. Skills, competences and activities required in these processes are exactly the same in the R\&D innovation process (Kim 1997). At this stage of competition, global corporations are very favourable to leave R\&D aimed at radical innovations, becoming increasingly vulnerable in terms of competitive position, and adopt policies directed to extend the product lives with a series of incremental innovations adding new values.

In the global competitive landscape, corporations have to respond to the innovations and pioneering actions of their competitors, with responses which must include not only the ability to prevent others from imitating, but also the ability to imitate the others. 
Imitation can be unique if it consists of a set of activities that are distinct in their derivative form or combinative architecture. Together with organizational capabilities and distinctive intangible assets (such as corporate culture, information system and corporate identity) imitation can be a differentiating factor and has the potential to deliver unique value.

Imitation is a critical capability for any global firm. In fact, in global markets, it is unrealistic for any firm to innovate anywhere and anytime. The imitation is as rare and valuable as innovation, but imitation policies can be strategically conceived and systematically executed with specific and focused R\&D (Brondoni 2012).

\section{Network Management, Outside-In Capabilities and Smart Innovation for Customers Empowerment in Global Competition}

In global over-supplied markets, firms must interact directly with customers, and they radically reorganize the client-product relationship on the objectives of specific empowerments. In a customer-centric firm the scope of market analysis shifts from an aggregate view to an individual view of customer activities. As a consequence, market research shifts its attention in acquiring the customer input that will drive improvements by customer-metrics focused on new product features (research for customers empowerment). To make sure that a 'new' virtual product reflects real-world needs, the customer must be brought into the design process, integrating $\mathrm{R} \& \mathrm{D}$ and marketing to prototype new products and new features for existing products (Campbell et al. 2007).

Over-supplied markets emphasises the critical nature of research for customers empowerment because the condition of excess of production presents strongly unstable demand (choices among different product classes and products with different uses; preference volatility; non-loyalty and disloyalty purchase behaviour) and unstable supply structures (planned innovation acceleration; production delocalisation; creation of demand bubbles). In over-supply competition, research for customers empowerment maximises the opportunity to produce goods with specific features (derived from computer-based information) and meets customer expectations to satisfy specific demand bubbles.

Demand bubbles derive from an aggregation process (significantly different from a disaggregation process that results in segmentation in stable markets) that tends to create specific, highly unstable forms of demand (Corniani 2005). On the other hand, managing market instability presupposes the capacity for rapid development and exploitation of the demand bubble. This, in turn, imposes a continuous action aimed at identifying offers that follow one another over time and which are able to interest and satisfy groups of final consumers (Brondoni 2003)

In general, manufacturer gives preference to product features based on the speed with which they exit from the outlets (focusing more attention on product rotation than on margin of contribution, as happens for decisions about segmentation in stable markets) (Reinartz 2002).

The ability of an enterprise to introduce successful products or services in a timely manner is of critical importance in generating the firm profitability. Product introduction has become a synchronized task across global markets, tackling multiple 
countries simultaneously. Synchronizing product localization, customer support services, etc. is a goal of great complexity. Companies must successfully execute both product development and product introduction, and the associated logistics, in order to compete focusing on outside-in capabilities (Baradello, Salazzaro 2012).

$\square$ Samsung make things smart and believes being smart is more than being connected. Samsung Research is a team of cross-skilled engineers, designers and makers with an amazing mandate: to invent and innovate new multi-device experiences across Samsung device ecosystem and beyond in the Internet of Things (IoT) domain. Samsung passion is to create drastically simple experiences covering smart devices, smart objects and smart spaces which our customers love and which make their life better and easier. Samsung Research works very hard to develop technologies to make things very simple for their customers. Technologies that can relieve users from many of tedious tasks and steps that have become accustomed to when using connected phones, TV's, etc. The experiences that Samsung builds, 'They Just Happen', like magic. The features and products that Samsung develops observe the users, predict their needs and act on their behalf right when they need it.

Furthermore, global competition poses a great pressure on prices and margins. Thus, corporations need to optimize the way they source components and subsystems globally by seeking to obtain unique advantages in terms of cost, time-to-market, access to highly skilled human capital, minimization of risks of supply chain disruption, access to government incentives and subsidies.

The complexity of this process is heightened by the fact that multi-disciplinary teams (real, virtual, co-located, and dispersed all over the globe) need to come together with the purpose of delivering a new product or service within the agreed-upon budgetary and time constraints. The product team will be measured by its ability to deliver on the promises made to key stakeholders of the firm (i.e. shareholders, customers, employees, and the surrounding community) in terms of revenues, market share, profitability and customer satisfaction. Global supply chain management is critical and a worldwide product design crossroads technological innovations and market needs (Baradello, Salazzaro 2012)

Global corporations are facing increasingly complex environments. Models for managing complexity are needed, and with its systemic approach, information design brings concrete answers to complexity management.

\section{Emerging Issues: Chief Customer Officers (CCO) and Chief Marketing Officers (CMO) for Smart Innovation}

In discontinuous markets where digitalisation has produced a plethora of new products, customer experience is an effective instrument to create and manage the competitive product differentiation. Therefore the customer experience is focused on client profitability and will replace competitive differentiation through mere product features and product variants. So, value creation in mass markets is no 
longer produced into the companies, but is developed by interactions with the consumers. Firms operating in mature markets, have to invest considerably in researching valuable customer experience, even if it is more complex to design a product on an experience-basis than to develop a product on a market data-basis because more functions and points need to be taken into account. The costs of creating, developing, and then launching new products have risen tremendously (for example, the cost of developing a new drug, or launching a new fast moving consumer good into a distribution channel) (Brondoni 2012). Besides, global imitation and shortening product life cycles mean that even great technologies no longer can be relied upon to maintain a satisfactory profit before they become a commodity. The involvement of the customer in the design and production process is a strategy in which corporations are using Internet and computer technologies to innovate the products and to limit the R\&D costs.

In global markets, chief marketing officers must find out who customers are, what they want and how they would like to interact with the organization. Chief marketing officers are really unprepared to take charge of the growing volume, velocity and variety of data arising from the data explosion, proliferation of channels and devices, and shifting consumer demographics. Chief marketing officers are also underprepared to use customer analytics, customer relationship management (CRM), social media and mobile applications. When chief marketing officers rely on traditional sources of information, such as market research and competitive benchmarking, they are not able to make strategic decisions because these sources only show customers in aggregate, offering little insight into what individual customers need or desire.

In global corporations marketing departments tend to believe that the sales force is myopic -too focused on individual customer experiences, insufficiently aware of the larger market, and blind to the future landscapes. Sales departments, on the contrary, believe that marketers are out of touch with what's really going on in the marketplace (Kotler, Rackham, \& Krishnaswamy 2006).

Marketing departments and sales departments are both far away from R\&D departments that must face global product imitation and innovation (Corniani 2012). On global market-space, the marketing department has to change in a customer department, and the chief marketing officer must be replaced by the chief customer officer that oversees customer-focused functions including CRM, customer service, marketing research, market research, and R\&D with research for customers empowerment.

The fundamental principle of product design based on experience is therefore to think beyond the product and create meaningful interactions with customers of many countries that are the vital part of the experience using the opportunities offered by the network's outside-in capabilities. Compared to traditional new product development research, the systemic view of experience design implies three major differences. The customer is seen as a co-creator and the product value is no longer created by the firm only, but in cooperation with the customer. While the product has been at the centre of new product development, customers empowerment poses the product as the result of customer interactions.

In digital research for customers empowerment, co-creation is not necessarily based on a company-customer relationship. Independent users can connect and presume content in pairs, groups or virtual communities (Reichwald, Bullinger 
2008). In this case, the most famous example is the Linux community, in which cocreation goes beyond customer involvement as it is proposed by new product development research (customer-based idea generation and acceptance testing) (von Hippel 2005; Gruner, Homburg 2000).

Firms are looking for new ways to connect with their customers accelerating key business processes such as marketing, sales, supply chain and customer service, driving faster business results.

$\square$ Coca-Cola Smart is Coca-Cola's product ordering and fulfillment
website. It is a system that will revamp the entire ordering process and
even has the built-in intelligence to generate proposed Freestyle $\mathrm{TM}$
orders for clients. Try it and discover a taste for its refreshing
innovation. Currently, customers can order products for the Coca-Cola
Freestyle dispenser. Food Service Distributors can order syrup
products."

Global companies transform operations centred on their customers re-engineering design processes to meet the preferences of their key-clients, focusing on specific means as computer intelligent-guided customer experiences, mobile-first business and the cloud computing (cloud computing encompasses many areas of tech, including software as a service; cloud computing services are all delivered over the Internet, on demand, from massive data centres) (IBM 2012).

Meeting customers' expectations requires insight, innovation and a system of engagement that delivers an intelligent guided customer experience. Firms competitors-driven have the ability to scan who is looking for what product features and make offers to customers to meet their preferences.

With social media interactions, and advanced analytics, corporations will project what global customers are looking for. Sharpening analytics will help businesses across all industries anticipate and predict what customers want. Also social media has changed the role of both consumers and marketers, and is now a key channel for engaging with customers. Corporations now have immediate access to vast quantities of data concerning customers' expectations and interests. However, engaging with customers is not just about communicating with them. It is also about helping them enjoy the products and services they have bought. To do this, marketers need to look beyond the transaction and focus on the full customer relationship.

The intersection of technology (social media and analytics in marketing) and business transformation is driving systemic change in marketing. Chief customer officers are challenged by complexities related to new technologies, changing of consumer demographics, and growing quantities of data. They are also challenged as empowered customers -with access to more information than ever- are taking greater control of business relationships. The marketplace is moving faster than the marketing function (IBM 2012).

Interacting effectively with customers in the digital era has implications beyond marketing products and services. With global interactions, the vision of designing, engineering and marketing to a universe of one is realized. 
IBM has developed a comprehensive vision for how a $21^{\text {st }}$ century city can use technology to speed emergency response. Smarter cities of all sizes are capitalizing on new technologies and insights to transform their systems, operations and service delivery. Competition among cities to engage and attract new residents, businesses and visitors means constant attention to providing a high quality of life and vibrant economic climate. Forward-thinking leaders recognize that although tight budgets, new and innovative technologies can help turn challenges into opportunities. These leaders see transformative possibilities in using big data and analytics for deeper insights. Cloud for collaboration among disparate agencies. Mobile to gather data and address problems directly at the source. Social technologies for better engagement with citizens. Being smarter can change the way their cities work and help deliver on their potential as never before.

In global and over-supplied markets, chief customer officers must deliver value to empowered customers through design, finding out who these customers are, what they want and how they would like to interact with the organization in defining innovative product features. Chief customer officers must understand and deliver value to empowered customers; create lasting relationships with those customers; and measure marketing contribution to the business in relevant, quantifiable terms. Finally, chief customer officers must try to understand individuals as well as markets focusing on relationships, not just on transactions (IBM 2011).

\section{Bibliography}

Abernathy William J., Utterback James M. (1978) Patterns of Industrial Innovation, Technology Review, June-July, pp. 41-48.

Arora Ashish, Fosfuri Andrea, Gambardella Alfonso (2001) Markets for Technology and their Implications for Corporate Strategy, Industrial and Corporate Change, n. 2, pp. 419-451.

http://dx.doi.org/10.1093/icc/10.2.419

Arrigo Elisa (2012) Alliances, Open Innovation and Outside-in Management, Symphonya. Emerging Issues in Management (symphonya.unimib.it), 2: 53-65.

http://dx.doi.org/10.4468/2012.2.05arrigo

Asheim Bjorn T., Lawton Smith Helen, Oughton Christine (2011) Regional Innovation Systems: Theory, Empirics and Policy, Regional Studies, vol. 45, 7, pp.875-891.

Baradello Carlos S., Salazzaro Andrea (2012) The Role of Imitation in High-Tech Product Development, Symphonya. Emerging Issues in Management (symphonya.unimib.it), n. 1, pp. 57 71.

http://dx.doi.org/10.4468/2012.1.05baradello.salazzaro

Bellini Nicola, Hilpert Ulrich (eds.) (2013) Europe's Changing Regional Geography. The Impact of Inter- Networks, London, Routledge.

Bellini Nicola, Teräs Jukka, Ylinenpää Håkan (2012) Science and Technology Parks in the Age of Open Innovation. The Finnish Case, Symphonya. Emerging Issues in Management (symphonya.unimib.it), n. 1, pp. 25-44.

http://dx.doi.org/10.4468/2012.1.03bellini.teras.ylinenpaa

Beuker Ralf, Abbing Erik Roscam (2010) Two Faces of Social Media: Brand Communication and Brand Research, Design Management Review, march, n. 21, 1, pp. 54-60. 
http://dx.doi.org/10.1111/j.1948-7169.2010.00051.x

Bohemia Eric, Harman Kerry (2008) Globalization and Product Design Education: The Global Studio, Design Management Journal, December, 3 (2), 53-68.

http://dx.doi.org/10.1111/j.19487177.2008.tb00014.x

Bolton Michele K. (1993) Imitation versus Innovation: Lessons to Be Learned from the Japanese, Organizational Dynamics, Winter, pp. 30-45.

http://dx.doi.org/10.1016/j.bbr.2011.03.031

Borja De Mozota Brigitte, Young Kim Bo (2009) Managing Design as a Core Competency: Lessons from Korea, Design Management Review, 20 (2), 66-76.

http://dx.doi.org/10.1111/j.1948-7169.2009.00009.x

Brondoni Silvio M. (2013) Innovation and Imitation for Global Competitive Strategies. The Corporation Development Models of US, Japan, Korea, and Taiwan, Symphonya. Emerging Issues in Management (symphonya.unimib.it), n. 1, pp. 12 - 27.

http://dx.doi.org/10.4468/2013.1.02brondoni

Brondoni Silvio M. (2012) Innovation and Imitation: Corporate Strategies for Global Competition, Symphonya. Emerging Issues in Management (symphonya.unimib.it), n. 1, pp. 10-24.

http://dx.doi.org/10.4468/2012.1.02brondoni

Brondoni Silvio M. (2011) Global Networks, Knowledge Management and World Cities, Symphonya. Emerging Issues in Management (symphonya.unimib.it), n. 1, pp. 7-18.

http://dx.doi.org/10.4468/2011.1.02brondoni

Brondoni Silvio M. (2010) Intangibles, Global Networks \& Corporate Social Responsibility, Symphonya. Emerging Issues in Management (symphonya.unimib.it), n. 2, pp. 6-24.

http://dx.doi.org/10.4468/2010.2.02brondoni

Brondoni Silvio M. (2008) Market-Driven Management, Competitive Space and Global Networks, Symphonya. Emerging Issues in Management (symphonya.unimib.it), n. 1, pp. 14-27.

http://dx.doi.org/ 10.4468/2008.1.02brondoni

Brondoni Silvio M. (2003) Ouverture de 'Marketing Research and Global Markets', Symphonya. Emerging Issues in Management (symphony.unimib.it), n. 2, pp. 1-16.

http://dx.doi.org/ 10.4468/2003.2.01ouverture

Brondoni Silvio M. (2002) Global Markets and Market-Space Competition, Symphonya. Emerging Issues in Management (symphonya.unimib.it), n. 1, pp. 28-42.

http://dx.doi.org/10.4468/2002.1.03brondoni

Bruce Margaret, Jevnaker Birgit H. (eds.) (1998). Management of Design Alliances: Sustaining Competitive Advantage, Wiley, Chichester

Byun Byung-Moon, Ahn Byung-Hun (1989) Growth of the Korean Semiconductor Industry and Its Competitive Strategy in the World Market, Technovation, n. 9, pp. 635-656.

http://dx.doi.org/10.1016/j.bbr.2011.03.031

Cambra-Fierro Jesus J., Hart Susan, Fuster Mur Ana, Polo Redondo Yolanda (2011) Looking for Performance: How Innovation and Strategy May Affect Market Orientation Models, Innovation: Management, Policy \& Practice, vol. 13, n. 2, pp. 154-172.

http://dx.doi.org/10.5172/impp.2011.13.2.154

Campbell R. Ian, De Beer Deon J., Barnard L.J., Booysen G.J., Truscott M., Cain R., Burton M.J., Gyi D.E., R. Hague R., (2007) Design Evolution through Customer Interaction with Functional Prototypes, Journal of Engineering Design, n. 18, 6, pp. 617-635.

http://dx.doi.org/ 10.1080/09544820601178507

Cappellin Riccardo, Wink, Rudiger (2009) International Knowledge and Innovation Networks: Knowledge Creation and Innovation in Medium Technology Clusters, Edward Elgar Publishing, Cheltenham

Caves Richard (1982) Multinational Enterprise and Economic Activity, Cambridge University Press, Cambridge. 
Chesbrought Henry (2003) The Logic of Open Innovation: Managing Intellectual Property, California Management Review, vol. 45, n. 3, pp. 33-58.

http://dx.doi.org/10.2307/41166175

Cohen Wesley M., Levinthal Daniel A. (1989) Innovation and Learning: The Two Factors of R\&D, The Economic Journal, September, n. 99, pp. 469-596.

Corniani Margherita (2012) Innovation, Imitation and Competitive Value Analysis, Symphonya. Emerging Issues in Management (symphonya.unimib.it), n. 2, pp. 37-52.

http://dx.doi.org/10.4468/2012.2.04corniani

Corniani Margherita (2006) Digital Marketing Communication, Symphonya. Emerging Issues in Management (symphonya.unimib.it), n. 2, pp. 41-61.

http://dx.doi.org/ 10.4468/2006.2.04corniani

Corniani Margherita (2005) Market, Demand Segments and Demand Bubbles, Symphonya. Emerging Issues in Management (symphonya.unimib.it), n. 2, pp. 13-30.

http://dx.doi.org/10.4468/2005.2.02corniani

Darroch Jenny (2005) Knowledge Management, Innovation and Firm Performance, Journal of Knowledge Management, vol. 9, n. 3, pp. 101-115.

http://dx.doi.org/10.1108/13673270510602809

de Leersnyder, Jean-Marc (2002) Corporate Culture and Geopolitics, Symphonya. Emerging Issues in Management (symphonya.unimib.it), n. 2, pp. 44-53.

http://dx.doi.org/10.4468/2002.2.06deleersnyder

Doloi Hemanta (2007) Developing an Integrated Management System for Optimising Project Options, Journal of Enterprise Information Management, 20 (4), 465-486.

http://dx.doi.org/10.1108/17410390710772722

Dunning John H., Lundan Sarianna M. (2008) Multinational Enterprises and the Global Economy, Edward Elgar, Northampton.

Dunning John H. (1993) The Globalization of Business: the Challlenge of 1990's, Routledge, London.

Feitzinger Edward, Lee Hau L. (1997). Mass Customization at Hewlett-Packard: The Power of Postponement, Harvard Business Review, January/February, n. 75, 1, pp. 116-121.

Grossman Gene M., Helpman Elhanan (1991) Innovation and Growth in the Global Economy, The MIT Press, Cambridge, Massachusetts.

Gruner Kjell E., Homburg Christian (2000) Does Customer Interaction Enhance New Product Success?, Journal of Business Research, July, n. 49, 1, pp. 1-14.

http://dx.doi.org/10.1016/SO148-2963(99)00013-2

Hassenzahl Marc, Tractinsky N, (2006) User Experience. A Research Agenda, Behaviour \& Information Technology, n. 25, 2, pp. 91-97.

http://dx.doi.org/10.1080/01449290500330331

Helpman Elhanan (1993) Innovation, Imitation and Intellectual Property Rights, Econometrica, November, pp. 1247-1280.

IBM, (2012). IBM Helps Global Industry Leaders Connect with the Chief Executive Customer, IBM, The Smarter Commerce Global Summit, September, Orlando.

IBM, (2011). From Stretched to Strengthened: Insights from the Global Chief Marketing Officer Study, IBM Global Business Services, October, New York.

Inauen Matthias, Schenker-Wicki Andrea (2011) The Impact of Outside-in Open Innovation on Innovation Performance, European Journal of Innovation Management, vol. 14, n. 4, pp. 496-520. http://dx.doi.org/10.1108/14601061111174934

Lambin Jean-Jacques (2014) Rethinking the Market Economy. New Challenges, New Ideas, New Opportunities, Palgrave Macmillan, London.

Lambin Jean-Jacques (2009) Ouverture de 'Market-Driven Management and Competitive Customer Value - 2', Symphonya. Emerging Issues in Management (symphonya.unimib.it), n. 2, pp. 1-2. 
http://dx.doi.org/10.4468/2009.2.01ouverture

Lambin Jean-Jacques (2000) Market-Driven Management: Strategic and Operational Marketing, MacMillan, London.

Lambin Jean-Jacques, Brondoni Silvio M. (2001) Ouverture de 'Market-Driven Management', Symphonya. Emerging Issues in Management (symphonya.unimib.it), n. 2, pp. 1-11.

http://dx.doi.org/10.4468/2001.2.01ouverture

Levitt Theodore (1966) Innovative Imitation, Harvard Business Review, September-October, 63-70.

Link Albert, Neufeld John (1986) Innovation Versus Imitation: Investigating Alternatives R\&D Strategies, Applied Economics, December, pp. 1359-1363. http://dx.doi.org/10.1080/00036848600000009

Kim Linsu (1997) Imitation to Innovation: The Dynamics of Korea's Technological Learning, Harvard University School Press, Cambridge, Massachusetts.

Koo Yoori, Cooper Rachel (2011) Managing Corporate Social Responsibility Through Design, Design Management Review, March, 22, 1, pp. 68-79.

http://dx.doi.org/10.1111/j.1948-7169.2011.00112.x

Kotler Philip, Rackham Neil, Krishnaswamy Suj, (2006). Ending the War Between Sales \& Marketing, Harvard Business Review, July/August, n. 84, 7/8, pp. 68-78.

Mansfield Edwin, Schwartz Mark, Wagner Samuel (1981) Imitation Costs and Patents: An Empirical Study, The Economic Journal, n. 91, 907-918.

Meyers Patricia W. (1990) Nonlinear Learning in Large Technological Firms: Period Four Implies Chaos, Research Policy, n. 19, pp. 97-115.

http://dx.doi.org/10.1016/j.bbr.2011.03.031

Reichwald Ralf, Bullinger Angelika, (2008). Innovation and Ontologies: Structuring the Early Stages of Innovation Management, Springer, Munchen.

Reinartz Werner (2002) Customizing Prices in Online Markets, Symphonya. Emerging Issues in Management (symphonya.unimib.it), n. 1, pp 55-65.

http://dx.doi.org/10.4468/2002.1.05reinartz

Rust Roland T., Moorman Christine, Bhalla Gourav, (2010). Rethinking Marketing, Harvard Business Review, January/February, n.88, 1/2, pp. 94-101.

Schnaars Steven P. (1994) Managing Imitation Strategy: How Later Entrants Seize Markets from Pioneers, The Free Press, New York.

Utterback James M., Kim Linsu (1985) Invasion of Stable Business by Radical Innovations, in Kleindorfer Paul R. (ed.), Management of Productivity and Technology in Manufacturing, Plenum Press, New York.

von Hippel Eric (2005). The Democratization of Innovation, MIT Press, Cambridge.

von Hippel Eric (1988). The Sources of Innovation, MIT Press, Cambridge.

von Stamm Bettina (2004). Innovation. What's Design Got to Do with It?, Design Management Review, 15 (1), Winter,10-19.

http://dx.doi.org/10.1111/j.1948-7169.2004.tb00145.x

Vorhies Douglas W., Harcher Michael (2000) The Capabilities and Performance Advantage of Market-Driven Firms: An Empirical Investigation, Australian Journal of Management, September, n. 25, pp. 145-171.

http://dx.doi.org/10.1177/031289620002500203

Weerawardena Jay, O'Cass Aron (2004) Exploring the Characteristics of the Market-Driven Firms and Antecedents to Sustained Competitive Advantage, Industrial Marketing Management, July, $\mathrm{n}$. 33, pp. 419-428.

Wind Jerry, Mahajan Vijan, Digital Marketing (2002) Symphonya. Emerging Issues in Management (symphonya.unimib.it), n. 1, pp. 43-54.

http://dx.doi.org/10.4468/2002.1.04wind.mahajan 